Vol. 1 | No. 3 | Juli 2020 | Hal. 251 - 258

\title{
PENYULUHAN HUKUM UNTUK MEWUJUDKAN MASYARAKAT ANTI PENYALAHGUNAAN NARKOTIKA DAN PSIKOTROPIKA
}

\author{
Fitria Dewi Navisa, Marita Lely Rahmawati, Muhammad Rizaldi Hendriawan, Sofiatul \\ Istiqomah, Indah Iftiati, Risky Akbar, Aditya Andika Kameswara, Muhammad Syeisar \\ Nanda P., Tri Anjas Andi Prsetyo, Hikmatul Azizah \\ Fakultas Hukum, Universitas Islam Malang
}

Korespondensi email: navisa@unisma.ac.id

\begin{abstract}
ABSTRAK
Narkotika dan Psikotropika merupakan obat-obatan yang hanya boleh digunakan untuk kepentingan kesehatan dan/atau pengembangan ilmu pengetahuan. Penyalahgunaan narkotika dan/atau psikotropika dapat mengakibatkan berbagai dampak buruk bagi kesehatan bahkan dapat pula menyebabkan kematian. Namun demikian penyalahgunaan Narkotika dan Psikotropika marak terjadi di berbagai negara termasuk Indonesia. Yang memprihatinkan, Pelaku Penyalahgunaan Narkotika dan/atau Psikotropika tidak hanya berasal dari kalangan orang dewasa tetapi juga berasal dari kalangan remaja. Masih terdapat pula masyarakat yang tidak terlalu memahami apa itu Narkotika, Psikotropika, apa dampak buruk yang dapat diakibatkan oleh penyalahgunaan Narkotika dan/atau Psikotropika serta apa sanksi hukum yang dapat mereka hadapi apabila mengkonsumsi Narkotika dan/atau Psikotropika tanpa hak atau melawan hukum. Masyarakat demikian rentan menjadi sasaran bandar Narkoba. Oleh karena itu, dengan dilaksanakannya program kerja penyuluhan hukum ini diharapkan dapat meningkatkan pengetahuan masyarakat terkait aturan hukum tentang Narkotika, Psikotropika dan pidana bagi remaja yang melakukan tindak pidana sehingga masyarakat khususnya remaja mematuhi aturan hukum yang berlaku.
\end{abstract}

Kata Kunci: narkotika; psikotropika; tindak pidana anak.

\section{PENDAHULUAN}

Hukum merupakan perangkat aturan yang tertulis maupun tidak tertulis yang mengatur kehidupan masyrakat. Hukum yang paling baik adalah hukum yang ada di masyarakat (Hermawan Usman, 2014). Memberikan edukasi-edukasi hukum kepada masyarakat merupakan hal yang wajib dilakukan terutama bagi mahasiswa fakultas hukum. Mahasiswa Fakultas Hukum Universitas Islam Malang melakukan penyuluhan hukum dengan judul tindak pidana narkotika, psikotropika, dan tindak pidana anak dikarenakan permasalahan narkoba di Indonesia merupakan sesuatu yang bersifat urgent dan kompleks (Muzakir, Junaid, \& Prasetya, 2018). Dalam kurun waktu satu dekade terakhir permasalahan ini menjadi marak. Terbukti dengan bertambahnya jumlah penyalahguna atau pecandu narkoba secara signifikan, seiring meningkatnya pengungkapan kasus tindak kejahatan narkoba yang semakin beragam polanya dan semakin massif pula jaringan sindikatnya. Dampak dari penyalahgunaan narkoba tidak hanya mengancam kelangsungan hidup dan masa depan penyalahgunanya saja, namun juga masa depan bangsa dan negara, tanpa membedakan strata sosial, ekonomi, usia 
maupun tingkat pendidikan. Sampai saat ini tingkat peredaran narkoba sudah merambah pada berbagai level, tidak hanya pada daerah perkotaan saja melainkan sudah menyentuh komunitas pedesaan. Hal inilah yang menjadi kewaspadaan bagi kita, untuk selalu melakukan upaya pencegahan pada berbagai tingkatan (Lusia Sinta Herindrasti, 2018).

Permasalahan narkoba sudah mewabah di hampir semua negara di dunia, akibatnya jutaan jiwa mengalami ketergantungan narkoba, menghancurkan kehidupan keluarga, mengancam keamanan dan ketahanan berbangsa dan bernegara. Berdasarkan laporan badan dunia peserikatan bangsa-bangsa untuk urusan narkoba dan kejahatan, UNODC (United Nations Office On Drugs Crimes), upaya pengawasan narkoba yang ketat oleh negara-negara di dunia telah dapat mengendalikan peredaran narkoba di Eropa, Amerika dan Asia.Namun transaksi dan peredaran narkoba yang dilakukan oleh pelaku kejahatan terorganisir (Organized Crime) ternyata terus meningkat sehingga perlu diperlukan berbagai macam upaya untuk untuk melindungi masyarakat dari bahaya penyalahgunaan narkoba. Penyalahguna narkoba menduduki rangking 20 dunia sebagai penyebab angka kematian dan rangking ke 10 di negara sedang berkembang, termasuk Indonesia. Penyalahguna narkoba diketahui sangat rentan dan mudah terjangkit HIV, Hepatitis dan Tubercolis, yang kemudian dapat menular ke masyarakat umum. Atas dasar inilah UNODC menganggap penyalahgunaan narkoba merupakan masalah kesehatan. Dalam lingkup Negara Republik Indonesia, tingkat penyalahgunan narkoba memberikan dampak yang luar biasa signifikan. Baik dari sisi sosial maupun ekonomi. Berdasarkan data yang dihimpun oleh BNN, dari tingkat pembiayaan urusan yang berkaitan dengan narkoba, negara mengeluarkan anggaran sekitar 45 triliun, dengan perincian untuk membiayai Rehabilitasi, pengobatan maupun proses hukum. Angka ini sangat fantastis untuk ukuran Indonesia yang masih dalam tataran berkembang (Supriyanto, 2015).

Penggunaan narkotika dan obat-obatan terlarang (narkoba) di kalangan remaja dinilai memprihatinkan. Tidak hanya itu, angka pengguna narkoba di Ibu Kota DKI Jakarta, juga terbilang tinggi. Berdasarkan data Badan Narkotika Nasional (BNN) 2,2\% dari total populasi orang di Indonesia terjerat narkoba (Amanda, Humaedi, \& Santoso, 2017). Berdasarkan hasil penelitian Azmiardi (2020) di Provinsi Jawa Tengah, terdapat sekitar $500 \mathrm{ribu}$ penduduk yang terlibat dalam penyalahgunaan obat-obatan terlarang tersebut. Sedangkan, penggunaan narkoba di wilayah DKI Jakarta mencapai angka 7\% dan merupakan angka tertinggi dibandingkan dengan kota lain. Kota lain rata-rata hanya berada pada angka 2,2\% pengguna dari jumlah penduduknya, selisih 4,8\% dibandingkan dengan Jakarta.

Hingga kini penyebaran narkoba sudah hampir tak bisa dicegah. Mengingat hampir seluruh penduduk dunia dapat dengan mudah mendapat narkoba dari oknum-oknum yang tidak bertanggung jawab (Idrus, Sakung, \& Moonti, 2018). Misalnya saja dari bandar narkoba yang senang mencari mangsa didaerah sekolah, diskotik, tempat pelacuran, dan tempat-tempat perkumpulan geng. Tentu saja hal ini bisa membuat para orang tua cemas, pemerintah khawatir akan penyebaran narkoba yang begitu meraja lela (Amanda et al., 2017).

World Drugs Reports 2018 yang diterbitkan United Nations Office on Drugs and Crime (UNODC), menyebutkan sebanyak 275 juta penduduk di dunia atau 5,6\% dari penduduk dunia (usia 15-64 tahun) pernah mengonsumsi narkoba (Siregar, 2019). Sementara di Indonesia, BNN selaku focal point di bidang Pencegahan dan Pemberantasan Penyalahgunaan dan Peredaran Gelap Narkoba (P4GN) mengantongi angka penyalahgunaan narkoba tahun 2017 sebanyak 3.376.115 orang pada rentang usia 10-59 tahun. Sedangkan angka penyalahgunaan Narkoba di kalangan pelajar di tahun 2018 (dari 13 ibukota provinsi di Indonesia) mencapai angka 2,29 juta orang. Salah satu kelompok 
masyarakat yang rawan terpapar penyalahgunaan narkoba adalah mereka yang berada pada rentang usia 15-35 tahun atau generasi milenial.

Menurut Octavia (2018) Ada beberapa penyebab tersering mengapa remaja sangat rentan terhadap penyalahgunaan narkoba adalah sebegai berikut:

\section{Tekanan sosial}

Masa remaja merupakan masa pencarian jati diri. Sering kali para remaja mengikuti apa pun yang dilakukan teman atau kelompoknya, agar diterima dalam lingkaran sosial. Oleh karena itu, jika teman sekelompok atau idolanya mencoba hal yang negatif seperti narkoba, mereka pun rentan untuk melakukan hal yang sama agar tidak dikucilkan. Paparan media seperti media sosial, serial televisi, atau film juga dapat memberikan efek negatif lantaran menggambarkan pemakai narkoba sebagai orang yang terlihat keren, sehingga rentan diikuti oleh para remaja lainnya.

\section{Pelarian dari masalah}

Masalah di sekolah, di rumah, atau pertengkaran dengan pacar bisa membuat seorang remaja merasa tidak bahagia dan mencari pelarian ke hal lain. Bentuk pelarian dari ini bisa berujung pada hal negatif, seperti narkoba atau alkohol. Narkoba menjadi yang paling sering dipilih sebagai pelarian karena seolah memberikan solusi. Hal ini karena narkoba bisa memberikan efek percaya diri, bahagia, dan berenergi, meski hanya sesaat. Padahal jika dibiarkan, justru dapat membuat kecanduan narkoba dan berujung pada kehilangan nyawa.

\section{Bentuk pemberontakan}

Remaja yang berani mencoba hal baru dan menjadi pionir biasanya akan menonjol dan dipandang oleh kelompoknya. Hal itu bisa membuat remaja yang haus akan pengakuan dari teman-temannya untuk mencoba pengalaman baru, termasuk mencoba narkoba. Narkoba seolah menjadi "amunisi" bagi para remaja untuk bertindak lebih berani dan agresif. Narkoba jenis methamphetamine atau yang lebih dikenal dengan istilah sabu dapat membuat remaja bertindak kasar, agresif, atau bahkan membahayakan bagi orang lain.

\section{Kurang percaya diri}

Berbicara di depan umum, tampil pada pentas sekolah, atau sekadar mengajak lawan jenis bicara dapat menjadi masalah bagi remaja yang kurang percaya diri. Narkoba sering kali menjadi solusi bagi remaja yang demikian. Penggunaan narkoba jenis tertentu memang dapat memberikan efek sesaat, seperti menjadi lebih percaya diri dan tidak takut melakukan hal apa pun. Namun efek samping yang timbul setelah itu bisa sangat berbahaya, bahkan hingga berujung pada kematian seketika.

\section{Kesenangan sesaat}

Meski awalnya hanya iseng mencoba narkoba untuk kesenangan sesaat, namun kebahagiaan semu ini dapat membuat remaja kecanduan untuk mencobanya lagi dan lagi. Agar intensitas euforia itu bisa menetap, lama-kelamaan dibutuhkan dosis narkoba yang semakin tinggi. Akibatnya, mereka akan semakin sulit untuk bisa keluar dari "lingkaran setan" yang diciptakan narkoba.

Remaja dan mahasiswa dinilai sebagai target untuk dijadikan konsumen jangka panjang penyalahgunaan narkoba. (Suryawat, Widhyharto, \& Koentjoro, 2015). Tidak hanya sebagai pengguna, terdapat pula remaja yang terlibat dalam peredaran gelap Narkotika. Undang-Undang Republik Indonesia Nomor 35 Tahun 2009 tentang Narkotika memberikan definisi Narkotika sebagai zat atau obat yang berasal dari tanaman atau bukan tanaman, baik sintentis maupun semi sintetis, yang dapat menyebabkan penurunan atau perubahan kesadaran, hilangnya rasa mengurangi sampai menghilangkan rasa nyeri, 
dan dapat menimbulkan ketergantungan, yang dibedakan ke dalam golongan-golongan sebagaimana terlampir dalam undang-undang ini (Undang-Undang Republik Indonesia Nomor 35 Tahun 2009 tentang Narkotika). Pasal 1 angka 1 Undang-Undang RI Nomor 5 Tahun 1997 memberikan definisi Penyalah Guna adalah orang yang menggunakan Narkotika tanpa hak atau melawan hukum dan Peredaran Gelap Narkotika adalah setiap kegiatan atau serangkaian kegiatan yang dilakukan secara tanpa hak atau melawan hukum yang ditetapkan sebagai tindak pidana Narkotika. Sedangkan Psikotropika adalah zat atau obat, baik alamiah atau sintetis bukan Narkotika, yang berkhasiat psikoaktif melalui seelektif pada susunan saraf pusat yang menyebabkan perubahan khas pada aktifitas mental dan perilaku. Penyalahgunaan Psikotropika dalam pengertian lain disebut penggunaan secara merugikan adalah penggunaan Psikotropika tanpa pengawasan dokter. Terdapat sanksi-sanksi pidana bagi orang yang menyalahgunakan dan/atau terlibat dalam peredaran gelap Narkotika dan/atau Psikotropika sekalipun pelakunya belum dewasa (anak).

Berdasarkan hasil wawancara dengan Ketua RW 02 Kelurahan Wonokoyo, Pengetahuan-pengetahuan hukum sebagaimana disebutkan di atas sangat penting bagi masyarakat wonokoyo agar masyarakat tidak terbujuk untuk memakai narkotika dan/atau psikotropika secara sembarangan, terutama remajanya. Pada tahun 2018 dan 2019 terungkap adanya kasus-kasus penyalahgunaan narkoba di Wonokoyo yang dilakukan oleh warga usia antara 20-40 tahunan. Tidak hanya sebagai penyalahguna, terdapat pula warga yang terlibat dalam peredaran gelap narkotika di RW 02. Di RW 02, belum ada kasus penyalahgunaan narkoba oleh anak namun diharapkan penyuluhan hukum dengan tema Tindak Pidana Narkotika, Tindak Pidana Psikotropika dan Tindak Pidana Anak yang diberikan mampu membuat warga terutama remajanya memahami dampak negative dari narkoba jenis Narkotika dan Psikotropika baik dari segi kesehatan maupun dari segi hukum sehingga mereka tidak terbujuk untuk ikut menggunakan Narkotika dan/atau Psikotropika. Selain mengadakan penyuluhan hukum tentang tindak pidana narkotika dan tindak pidana psikotropika juga menyampaikan tentang pidana bagi anak yang melakukan tindak pidana, bahwa menurut hukum pidana anak merupakan seseorang yang belum berumur 18 (delapan belas) tahun, termasuk anak yang masih dalam kandungan. Kenakalan anak yang mulai usia dini bisa menyebabkan masa depan atau cita-cita anak tersebut akan hilang, faktor keluarga yang merupakan faktor utama dalam pembentukan anak sangat berpengaruh. Memberikan pemahaman kepada masyarakat kelurahan wonokoyo terhadap proses pendidikan anak itu hal yang penting. Jangan sampai anak yang seharusnya mendapatkan rasa kasih sayang oleh orang tuanya ditelantarkan karena orangtuanya hanya sibuk mencari uang sehingga anak tersebut akhirnya tertarik untuk melakukan hal-hal negatif diantaranya mencoba Narkotika dan/atau Psikotropika.

\section{METODE}

Pelaksanaan KKN PPM Tematik tahun 2020 RW 02 kelurahan Wonokoyo, kecamatan kedungkandang Kota Malang Jawa Timur (Gambar.1) yang bertemakan Peningkatan pemahaman masyarakat terhadap hukum melalui penyuluhan hukum di RW 02 Kelurahan Wonokoyo dilaksanakan pada tanggal 19 Agustus 2020 yang dilakukan oleh 9 mahasiswa UNISMA. Pada pelaksanaan pengabdian kepada warga RW 02 kelurahan Wonokoyo, kecamatan kedungkandang Kota Malang ini kami selaku pemateri memberikan penjelasan dan pemaparan dengan menggunakan Power Point dan video yang berkaitan dengan tema yang diangkat. Metode yang digunakan dalam penyuluhan hukum ini menggunakan metode caramah dan tanya jawab. Melalui sesi tanya jawab diharapkan warga menanyakan materi yang kurang dipahami. Selanjutnya, materi penyuluhan dibagikan kepada warga yang hadir 
via Whats App dengan harapan warga yang hadir dapat lebih mudah menjelaskan materi penyuluhan kepada keluarga dan tetangga sekitarnya yang tidak dapat hadir dalam penyuluhan dikarenakan adanya batasan jumlah orang yang boleh berkumpul dalam satu acara dalam rangka mencegah penyebaran COVID-19. Acara penyuluhan hukum dapat terlaksana dengan baik berkat bimbingan Dosen Pembimbing Lapangan dan kerja sama dari pihak kelurahan, Ketua RW 02 dan warga RW 02.

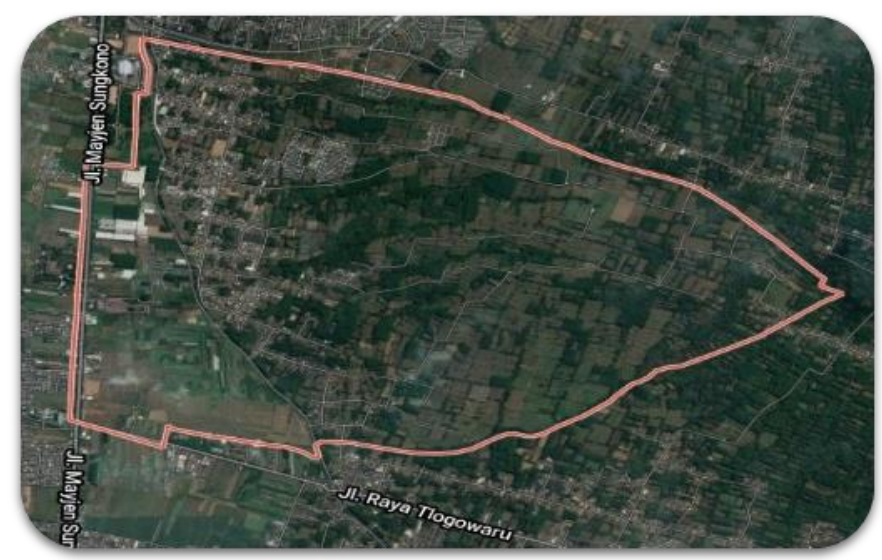

Gambar 1. Peta Lokasi Kegiatan KKN PPM Tematik di kelurahan Wonokoyo, kecamatan kedungkandang Kota Malang, Jawa Timur

\section{HASIL DAN PEMBAHASAN}

Kelurahan Wonokoyo terletak di wilayah timur Kota Malang, Provinsi Jawa Timur, dan berada $5 \mathrm{~km}$ dari pusat kota. Wilayah Kelurahan Wonokoyo terletak pada ketinggian 454 meter diatas permukaan laut. Kelurahan Wonokoyo memiliki luas 504 Ha yang terdiri dari 5 RW dan 27 RT. Warga RW 02 Kelurahan Wonokoyo, Kecamatan Kedungkandang, Kota Malang mayoritas matapencaharian penduduknya adalah petani.

Berdasarkan pemaparan Ketua RW 02, walaupun perekonomian warga RW 02 baik, namun mayoritas warga hanya menempuh Pendidikan hingga tingkat SD. Di RW 02 sendiri, warga asli yang menempuh pendidikan hingga sarjana, dapat dihitung dengan jari. Oleh karena itu tidak semua warga telah memahami mengenai apa itu narkotika dan psikotropika, serta apa dampak negatif baik dari segi kesehatan maupun dari segi hukum dari penyalahgunaan narkotika dan/atau psikotropika. Pemahaman akibat memakai Narkotika dan/atau Psikotropika serta perbuatan-perbuatan apa saja yang menurut Undang-Undang Republik Indonesia Nomor 35 Tahun 2009 tentang Narkotika dan Undang-Undang Republik Indonesia Nomor 5 Tahun 1997 tentang Psikotropika merupakan tindak pidana merupakan hal yang sangat penting. Warga RW 02 menyambut baik program kerja penyuluhan hukum tindak pidana narkotika, tindak pidana psikotropika dan tindak pidana anak. Mereka cukup antusias mengikuti acara tersebut. Dalam penyuluhan hukum tersebut yang dijelaskan adalah sebagai berikut:

1. Dalam Penyuluhan hukum tentang Tindak Pidana Narkotika dijelaskan bahwa penyalahgunaan Narkotika dapat menyebabkan dampak bagi kesehatan antara lain:

a. Dehidrasi

Penyalahgunaan narkotika dapat menyebabkan keseimbangan elektrolit dalam tubuh berkurang. Akibatnya badan kekurangan cairan. Jika efek ini terus terjadi, tubuh akan kejang-kejang, muncul halusinasi, perilaku lebih agresif, dan rasa sesak pada bagian dada. Jangka panjang dari dampak dehidrasi ini dapat menyebabkan kerusakan pada otak.

b. Halusinasi 
Halusinasi menjadi salah satu efek yang sering dialami oleh pengguna narkoba seperti ganja. Tidak hanya itu saja, dalam dosis berlebih juga bisa menyebabkan muntah, mual, rasa takut yang berlebih, serta gangguan kecemasan. Apabila pemakaian berlangsung lama, bisa mengakibatkan dampak yang lebih buruk seperti gangguan mental, depresi, serta kecemasan terus-menerus.

c. Menurunnya Tingkat Kesadaran

Pemakai yang menggunakan obat-obatan tersebut dalam dosis yang berlebih, efeknya justru membuat tubuh terlalu rileks sehingga kesadaran berkurang drastis. Beberapa kasus si pemakai tidur terus dan tidak bangun-bangun. Hilangnya kesadaran tersebut membuat koordinasi tubuh terganggu, sering bingung, dan terjadi perubahan perilaku. Dampak narkoba yang cukup berisiko tinggi adalah hilangnya ingatan sehingga sulit mengenali lingkungan sekitar.

d. Kematian

Dampak narkotika yang paling buruk terjadi jika si pemakai menggunakan obatobatan tersebut dalam dosis yang tinggi atau yang dikenal dengan overdosis. Pemakaian sabu-sabu, opium, dan kokain bisa menyebabkan tubuh kejang-kejang dan jika dibiarkan dapat menimbulkan kematian. Inilah akibat fatal yang harus dihadapi jika sampai kecanduan narkotika, nyawa menjadi taruhannya

Dampak buruk penyalahgunaan Narkotika jangka Panjang bagi kesehatan antara lain adalah sebagai berikut:

a. Gangguan mental

Pecandu atau pengguna narkotika dalam dosis tinggi misalnya heroin dalam jangka panjang dapat membuat zat-zat kimia dalam barang haram tersebut sistem sarafnya rusak dan merangsang kelainan perilaku seperi berhalusinasi, ilusi dan gangguan cara berpikir yang memicu gangguan.

b. HIV AIDS

Pengguna narkoba suntik diketahui turut menyumbang peningkatan jumlah orang yang terinfeksi HIV AIDS, hal ini karena sebagian besar pengguna narkoba menggunakan jarum suntik secara bergantian dan juga melakukan hubungan seksual yang tidak aman serta berganti-ganti pasangan. Umumnya seseorang tidak menyadari jika dirinya terinfeksi HIV karena sebagian besar tidak bergejala, sehingga rentan menularkan pada orang lain. Namun saat sistem kekebalan tubuhnya makin menurun maka mulai muncul gejala dan terkadang sudah masuk ke tahap AIDS.

Pemaparan dampak buruk penyalahgunaan narkotika tersebut dijelaskan untuk memberikan pemahaman kepada warga mengapa kemudian segala perbuatan yang terkait dengan Narkotika dan/atau Prekursor Narkotika diatur dalam ketentuan Undang-Undang. Selanjutnya dijelaskan kepada warga definisi Narkotika, Prekursor Narkotika, Penyalah Guna Narkotika menurut Undang-Undang Republik Indonesia Nomor 35 Tahun 2009 tentang Narkotika, golongan-golongan Narkotika berikut contohnya, jenis-jenis prekursor Narkotika berikut contohnya, dan terakhir ditunjukkan Pasal-Pasal mengenai ketentuan Pidana Tindak Pidana Narkotika dan Prekursor Narkotika.

2. Selain itu, penyuluhan hukum juga memberikan penjelasan tentang psikotropika. Bahwa psikotropika adalah zat atau obat, baik alamiah maupun sintetis bukan narkotika, yang berkhasiat psikoaktif melalui pengaruh selektif pada susunan saraf pusat yang menyebabkan perubahan khas pada aktivitas mental dan perilaku. Didalam penyuluhan hukum psikotropika ini kami memberikan perbuatan-perbuatan pidana apa saja yang dilarang dalam Undang-Undang No 5 Tahun 1997 Tentang Psikotropika. 
Misalnya Barangsiapa secara tanpa hak membawa, menyimpan dan/atau membawa psikotropika dipidana dengan pidana penjara paling lama 5 (lima) tahun dan denda paling banyak Rp 100.000.000,00 (seratus juta rupiah).

3. Penyuluhan hukum dengan tindak pidana anak menjelaskan kepada warga RW 02 Kelurahan Wonokoyo Kecamtan Kedungkandang Kota Malang, Bahwa anak merupakan asset yang paling berharga dalam keluarga. Proses pendidikan anak yang mengutamakan keberlangsungan hidup anak merupakan hal yang paling penting. Anak juga mendapatkan perlindungan dari sisi hukum. Perlindungan anak juga meliputi kepentingan terbaik bagi anak, nondiskriminasi, partisipasi dan kelangsungan hidup dan tumbuh kembang. Kenakalan anak bisa disebabkan oleh beberap hal misalnya faktor keluarga, pendidikan dan sekolah, pergaulan anak dan pengaruh media masa. Penyelesaian perkara pidana harus dipayakan melalui pendekatan keadilan restorative dan diversi. Diversi Menurut UU No 11 Tahun 2012 Pasal 1 angka 7, pengalihan penyelesaian perkara anak dari proses peradilan pidana ke proses di luar peradilan pidana. Diversi dimaksudkan untuk menghindari dan menjauhkan anak dari proses peradilan, sehingga dapat mencegah stigmatisasi terhadap anak yang berhadapan dengan hukum dan diharapkan anak dapat kembali ke dalam lingkungan sosial secara wajar. Tujuan dari mencapai perdamian antara korban dan anak, menyelesaikan perkara anak di luar peoses peradilan, menghindari anak dari perampasan kemerdekaaan, mendorong masyarakat untuk berpartisipasi, menanamkan rasa tanggung jawab kepada anak. Pasal 7 ayyat (2) UU No 11 Tahun 2012, maka dapat diketahui bahwa perkara anak yang wajib diupayakan diversi pada waktu dilakukan penyidikan, penuntutan, dan pemeriksaan sidang di pengadilan adalah perkara anak yang tindak pidananya:

a. Diancam dengan pidana penjara di bawah 7 (tujuh) tahun

b. Bukan merupakan pengulangan tindak pidana.

Proses diversi dilakukan mealui musyawarah dengan melibatkan anak dan orangtua wali atau walinya, korban dan/atau orangtua atau walinya, pembimbing kemasyarakatan, serta pekerja sosial professional berdasarkan pendekatan keadilan restoratif. Menurut Kamus Besar Bahasa Indonesia, yang dimaksud dengan musyawarah adalah pembahasan bersama dengan maksud mencapai keputusan atau penyelesaian masalah, Dilihat dari sudut pandang timbulnya kenakalan anak disebabkan oleh faktor: faktor keluarga, faktor pendidikan dan sekolah, faktor pegaulan anak dan pengaruh media massa.

\section{KESIMPULAN}

Bahwa narkotika, psikotropika sangat membahayakan apabila disalahgunakan oleh seseorang. Penyalahgunaan narkotik dan psikotropika bisa mengakibatkan depresi, halusinasi, kecanduan dan kematian. Narkotika dan psikotropika digunakan untuk kesehatan dan pengetahuan umum dan terdapat sanksi pidana bagi yang menyalahgunakannya. Penyuluhan hukum tindak pidana anak merupakan bagian dari sistem peradilan pidana. Anak adalah seseorang yang belum berumur 18 (delapan belas) tahun, termasuk anak yang masih dalam kandungan. Penyelesaian perkara pidana anak harus menggunakan pendekatan restorative bukan pembalasan. Penyelesaian perkara pidana anak harus melalui diversi Pasal 7 ayat (2) Undang-Undang No 11 Tahun 2012 tentang sistem peradilan pidana dengan syarat yakni ancaman pidananya dibawah 7 (tujuh) tahun dan bukan pengulangan tindak pidana sejenis maupun tidak sejenis. 


\section{UCAPAN TERIMA KASIH}

Ucapan terima kasih kami tujukan kepada seluruh perangkat Kelurahan Wonokoyo, Kecamatan Kedungkandang, Kota Malang dan Warga RW 02 yang telah menerima kami dengan tangan terbuka dan mendukung program-program kerja yang kami adakan sehingga seluruh program kerja tersebut dapat terlaksana dengan baik.

\section{DAFTAR RUJUKAN}

Amanda, M. P., Humaedi, S., \& Santoso, M. B. (2017). Penyalahgunaan Narkoba Di Kalangan Remaja (Adolescent Substance Abuse). Jurnal Penelitian \& PPM, 4(2), 339-345. https://doi.org/10.24198/jppm.v4i2.14392

Azmiardi, A. (2020). Pengaruh Perilaku Merokok, Konsumsi Alkohol dan Hiburan Malam terhadap Risiko Penggunaan Narkotika. Faletehan Health Journal, 7(1), 30-36. https://doi.org/10.33746/fhj.v7i1.86

Hermawan Usman, A. (2014). Kesadaran Hukum Masyarakat Dan Pemerintah Sebagai Faktor Tegaknya Negara Hukum Di Indonesia. Jurnal Wawasan Hukun, 30(1), 26-53. Retrieved from https://ejournal.sthb.ac.id/index.php/jwy/article/viewFile/74/55

Idrus, N. A. Al, Sakung, J., \& Moonti, S. W. (2018). Hubungan Tingkat Pengetahuan Dan Sikap Narapidana Dengan Penggunaan Narkoba Di Lembaga Permasyarakatan Klas IIB Kabupaten Tolitoli. Jurnal Kolaboratif Sains, 1(1), 835-842. https://doi.org/10.31934/jom.v1i1.419

Lusia Sinta Herindrasti, V. (2018). Drug-free ASEAN 2025: Tantangan Indonesia dalam Penanggulangan Penyalahgunaan Narkoba. Jurnal Hubungan Internasional, 7(1), 1933. https://doi.org/10.18196/hi.71122

Muzakir, Y. C., Junaid, \& Prasetya, F. (2018). Efektivitas Media Teka-Teki Silang Dengan Metode Nht (Number Heads Together) Terhadap Peningkatan Pengetahuan, Sikap Dan Tindakan Pencegahan Penyalahgunaan Narkoba Pada Siswa Kelas VIII di SMP Negeri 5 Kendari Tahun 2017. JIMKESMAS Jurnal Ilmiah Mahasiswa Kesehatan Masyarakat, 3(1), 1-9. https://doi.org/10.37887/jimkesmas.v3i1.3901

Octavia, N. (2018). Inilah Mengapa Remaja Rentan Kecanduan Narkoba. KlikDokter. Retrieved from https://www.klikdokter.com/info-sehat/read/3569916/inilahmengapa-remaja-rentan-kecanduan-narkoba

Siregar, R. A. (2019). Ancaman Narkoba Bagi Generasi Muda dan Upaya Pencegahan Serta Penanggulangannya. Jurnal Comunita Servizio, 1(2), 143-153. Retrieved from http://ejournal.uki.ac.id/index.php/cs/article/view/1284

Supriyanto, J. (2015). Pidana Mati Sebagai Sarana Pemberantasan Tindak Pidana Narkotika di Indonesia. Recidive, 4(3), 345-358. Retrieved from https://jurnal.uns.ac.id/recidive/article/view/40749

Suryawat, S., Widhyharto, D. S., \& Koentjoro. (2015). UGM MENGAJAK: RAIH PRESTASI TANPA NARKOBA. Yogyakarta: Gadjah Mada University Press. 